\title{
PRIVACY, SUPERINJUNCTIONS AND ANONYMITY “SELLING MY STORY WILL SORT MY LIFE OUT”
}

\author{
Robert Pearce ${ }^{1}$
}

\section{INTRODUCTION}

\subsection{The Adakini Ntuli Story}

In March 2010 Adakini Ntuli sent Howard Donald a text message in which she said:

"Why shud I continue 2 suffer financially 4 the sake of loyalty when selling my story will sort my life out?”

We do not know what her story was because Mr Donald, a member of the pop band Take That, obtained a superinjunction forbidding both publication of her story and disclosure of the existence of the injunction. The Court of Appeal later allowed the parties to be named, but not the details of their relationship. $^{2}$

The first known superinjunction, the Trafigura injunction, was not concerned with privacy, but prohibited disclosure of a legally privileged internal company report concerning alleged dumping of toxic waste. ${ }^{3}$ Injunctions preventing disclosure of confidential information have been available for almost two centuries. ${ }^{4}$ Their use to protect privacy is a controversial twenty-first century phenomenon which severely constrains the

\footnotetext{
${ }^{1}$ BCL, MA, Hon LLD, FRSA; Professor in Law, the University of Buckingham; Visiting Professor, the University of Gloucestershire; Emeritus Professor, University of Wales Trinity Saint David.

The author is grateful to Professor John Mee of University College Cork for helpful comments on a draft of this article. Responsibility for all faults remains with the author.

${ }^{2}$ Ntuli v Donald [2010] EWCA Civ 1276, [2011] 1 WLR 294.

${ }^{3}$ The case is discussed in the Neuberger Report (see n 7) paras 6.1 to 6.4. There is no publicly available judgment.

${ }^{4}$ Since Prince Albert v Strange (1849) 1 Mac \& G 25. A recent example is Imerman $v$ Tchenguiz [2011] 1 All ER 555.
} 
freedom of the press to publish "kiss and tell" and more serious stories. It has been speculated that the number of superinjunctions could exceed $200,^{5}$ although the absence of reliable statistics makes this hard to verify, and this figure may be an exaggeration or the result of differences in categorisation. ${ }^{6}$

The Neuberger Report (Report of the Committee on Super-Injunctions: Super-Injunctions, Anonymised Injunctions and Open Justice) ${ }^{7}$ divides injunctions concealing the identity of the claimant into two groups: anonymised injunctions, where only the identity of one or more of the parties is concealed, and superinjunctions which also order that the existence of the injunction itself be kept secret. ${ }^{8}$ Press comment often groups both kinds of injunction together. The Neuberger Report definitions suggest that all anonymised injunctions and superinjunctions are interim orders granted pending full trial although it acknowledges that it is possible for a permanent injunction to be granted securing indefinite secrecy or anonymity ${ }^{9}$ and to be enforceable contra mundum. ${ }^{10}$ Permanent anonymity orders are said in the Neuberger Report to be rare, ${ }^{11}$ but if the facts assumed at the interim stage are proved, and the balancing of competing rights requires it, there is no juridical reason why permanent protection should be refused. ${ }^{12}$

${ }^{5}$ See Privacy and Freedom of Expression: A Delicate Balance, lecture by Lord Neuberger at Eton, April $28^{\text {th }} 2010$.

${ }^{6}$ The Neuberger Report (see n 7) para 4.4. The Report recommended better data collection and a one year pilot scheme was introduced from August $1^{\text {st }} 2011$. The Guardian has produced a list of known superinjunctions: Butterworth and WolfeRobinson, Guardian online August $5^{\text {th }}$ 2011. Savage, The Daily Star online, May $15^{\text {th }}$ 2011 has a longer list.

${ }^{7}$ Report of the Committee on Super-Injunctions: Super-Injunctions, Anonymised Injunctions and Open Justice, May 2011 (the "Neuberger Report"). This is the report of a committee convened by Lord Neuberger, Master of the Rolls, to consider mainly procedural issues concerning the grant of superinjunctions and similar orders.

${ }^{8}$ There is also a category of injunction known as a "hyperinjunction" which additionally contains a prohibition on discussing issues with third parties: Neuberger Report paras 6.9-6.22.

${ }_{10}^{9}$ Neuberger Report para 2.37.

${ }^{10}$ OPQ v BJM [2011] EWHC 1059.

${ }_{11}^{11}$ Neuberger Report para 2.35.

12 See for instance Venables \& Thompson v News Group Newspapers Ltd [2001] EWHC QB 32; [2001] Fam 430 (See also Venables v News Group Papers Ltd [2010] EWHC B18); RST v UVW [2009] EWHC 2448, [2010] EMLR 13 (cited in the Neuberger Report para 2.35 as an instance where the absence of a return date, thus creating a potentially permanent injunction, was justified). 


\subsection{Open Justice}

It is a longstanding principle of English law ${ }^{13}$ that justice should be seen to be done, and that in consequence judicial hearings should take place in public. ${ }^{14}$ Open justice may have had its origins in trials being held in the Royal Courts, which were open places, but it is now justified by policy considerations, including "winning ... public confidence and respect,"15 exposing judges to scrutiny, ${ }^{16}$ and safeguarding against miscarriages of justice, such as false claims. ${ }^{17}$ As Jeremy Bentham said, "Publicity is the very soul of justice. It is the keenest spirit to exertion and the surest of all guards against improbity. It keeps the judge, while trying, under trial.”18

Some exceptions to open justice are the result of specific legislation, such as the general rule in the Court of Protection that proceedings are conducted in private and judgments are not made public. ${ }^{19}$ In addition the Courts have a general authority under the Civil Procedure Rules ${ }^{20}$ to grant anonymity where it is considered necessary. ${ }^{21}$ In late 2009, counsel remarked to the Supreme Court, "'Your first term docket reads like alphabet soup,"22 and Lord Rodger, acknowledged "how deeply ingrained has the habit of anonymisation become". ${ }^{23}$ The growth of exceptions to open justice has fuelled media

${ }^{13}$ Dating back to time immemorial: see Neuberger Open Justice Unbound, The Judicial Studies Board Annual Lecture, March $16^{\text {th }} 2011$.

${ }^{14}$ Spigelman, The Principle of Open Justice: A Comparative Perspective (Address by the Hon JJ Spigelman AC, Media Law Resource Centre Conference, September $20^{\text {th }}$ 2005).

${ }^{15}$ Scott v Scott [1913] AC 417 at 473 per Lord Shaw.

${ }^{16}$ Scott $v$ Scott [1913] AC 417 (Lord Diplock).

${ }^{17}$ JXF v York Hospitals NHS Foundation Trust [2010] EWHC 2800.

18 Bowling (ed) Works of Jeremy Bentham (1843) Vol 4 at 316-317, cited in Spigelman, $\mathrm{n} 14$ above.

${ }^{19}$ In exceptional cases, the hearing may be held in public and/or the judgment may be made public. See A v Independent News \& Media Ltd [2010] EWCA Civ 343; Hillingdon v Neary [2011] EWHC 413 (COP); W v M \& Ors [2011] EWHC 1197 (COP)

${ }^{20}$ Civil Procedure Rules 39.2. The Neuberger Report has recommended that these rules should be reviewed.

${ }^{21}$ The principles which govern the grant of anonymity in the reporting of a hearing (except where governed by specific statutory provisions) are the same or substantially the same as those which apply to the grant of superinjunctions and anonymised injunctions: $W v M$ [2011] EWHC 1197 (C).

${ }^{22}$ Re Guardian News and Media Ltd [2010] UKSC 1 at [1]. See Brennan What's in a name? [2010] Denning LJ 197-207.

${ }^{23}$ Ibid. 
concerns. ${ }^{24}$ Anonymised injunctions offend against the principle of open justice, and need special justification.

\section{RESPECT FOR PRIVACY}

\subsection{Protection of Privacy at Common Law}

One of the principal reasons for the upsurge in anonymity rulings is the incorporation into English law of the European Convention on Human Rights (the ECHR) by the Human Rights Act 1998 (the HRA). Before this there was no direct protection for privacy. The law of defamation offered protection only against falsehoods. When Gordon Kaye (the star of the BBC comedy series 'Allo 'Allo!) was recovering from brain surgery following a serious accident, a journalist and photographer gained access to his private hospital room, took photographs, and claimed to have interviewed him. The Court of Appeal stated simply: "in English law there is no right to privacy, and accordingly there is no right of action for breach of a person's privacy."25 Privacy could sometimes be protected indirectly through the action for breach of confidence, as when the Duke of Argyll was prevented from publishing information about his third wife's private conduct in the celebrated case of Argyll $v$ Argyll. ${ }^{26}$ Publishing the information, acquired by him during the course of the marriage, would have breached the confidential relationship between married couples.

All this changed with the implementation of the HRA. Most provisions of the the ECHR impose obligations on the State which are not directly enforceable against private citizens. Article 8 of the Convention, which states that "Everyone has the right to respect for his private and family life, his home and his correspondence" is different. The European Court of Human Rights (the European Court) has held that it imposes a positive obligation on the State, through the legislature and the courts, to respect, and therefore to promote, the interests of private and family life. As Buxton LJ said in McKennitt $v$ Ash, "That means that a citizen can complain against the state

24 See, for instance Telegraph online May $8^{\text {th }}$ 2011: Chef wins gagging order to suppress tribunal details where it was reported that despite opposition from two newspaper groups, no reasons were given for ordering anonymity for a celebrity chef: $J v$ K Ltd, Central London Employment Tribunal May 4th 2011

${ }^{25}$ Kaye $v$ Robertson (1991) FSR 62 at 66. An interlocutory injunction to restrain publication of the interview was granted on the ground that it was arguably a malicious falsehood to represent that the plaintiff had consented to it.

${ }^{26}$ [1967] Ch 302. 
about breaches of his private and family life committed by other individuals." ${ }^{27}$

The European Court has developed a substantial jurisprudence relating to privacy. The Court has held that Article 8's protection is broad. It includes protection for individuals wishing to express their own sexual identity ${ }^{28}$, protection from surveillance and interception of communications ${ }^{29}$, the right to develop one's own personality, ${ }^{30}$ and the right to create relationships with others $^{31}$, even in a public context. ${ }^{32}$

\subsection{Protection of Privacy now}

As a consequence of the HRA, the jurisprudence of the European Court has been "mainlined" into English law, creating an almost immediate impact upon the protection of privacy in domestic law. Recent cases create what can most accurately be described as a general principle of privacy, although as recently as 2004, the House of Lords maintained that there was no such high level principle, ${ }^{33}$ and that respect for privacy was essentially an extension of the tort of breach of confidence, ${ }^{34}$ which had in consequence been renamed as the "misuse of private information.",35

What the cases now very clearly establish is that where there is a "reasonable expectation of privacy", Article 8 of the ECHR is engaged and there is a prima facie case for protection. ${ }^{36}$ The reasonable expectation of privacy may arise from the way in which the information has been obtained, ${ }^{37}$

${ }^{27}$ [2006] EWCA Civ 1714 at [9].

28 Dudgeon v UK [1981] ECHR 5.

${ }_{30}^{29}$ Klass and others v Germany [1978] ECHR 4; Kennedy v UK [2010] ECHR 682.

${ }^{30}$ Botta v Italy [1998] ECHR 12.

${ }^{31}$ Niemietz v Germany [1992] ECHR 80; Jehova's Witnesses of Moscow v Russia [2010] ECHR 887.

${ }^{32}$ PG and JH v United Kingdom, [2001] ECHR 550; Peck v United Kingdom, [2003] ECHR 44.

${ }^{33}$ Wainwright $v$ Home Office [2004] 2 AC 406 at [28]-[35]. The case involved the strip search of visitors to a prisoner suspected of dealing in drugs.

${ }^{34}$ Douglas v Hello! Ltd (No3) [2006] QB 125 at [53].

35 Lord Nicholls of Birkenhead in Campbell v Mirror Group Newspapers Ltd [2004] 2 AC 457 at [14] and [21]. For a description of how the law concerning the protection of confidence has developed, see paras [43]-[48] (Lord Hoffman).

${ }^{36}$ Campbell v Mirror Group Newspapers Ltd [2004] 2 AC 457, at [21] per Lord Nicholls of Birkenhead, and Murray v Big Pictures (UK) Ltd [2008] EWCA Civ 446, at [24].

${ }^{37}$ Douglas v Hello! Ltd (No 3) [2005] EWCA Civ 595; AMM v HXW [2010] EWHC 2457. 
for instance by illegal means ${ }^{38}$ such as intercepting e-mails or telephone communications, ${ }^{39}$ where a message has been received by mistake, ${ }^{40}$ or through a traditional breach of confidence. ${ }^{41}$ In some cases weight has been placed on the fact that photographs have been taken surreptitiously with a camera smuggled into a private event ${ }^{42}$ or with the use of a telephoto lens, ${ }^{43}$ or that a private conversation has been covertly recorded. ${ }^{44}$ Deliberately targeting someone by "staking out" their home, or a place they are known to visit, may also be a relevant factor. ${ }^{45}$

Some information, regardless of the way it is obtained, will be considered inherently private, and therefore entitled to protection. The boundaries of this concept have yet to be well clarified. In Douglas v Hello! Ltd (No 3) Lord Phillips, delivering the judgment of the Court of Appeal asked:

"What is the nature of 'private information?' It seems to us that it must include information that is personal to the person who possesses it and that he does not intend shall be imparted to the general public."46

In Theakston v Mirror Group Newspapers $\operatorname{Ltd}^{47}$ Ouseley J declined to grant an injunction to prevent the Sunday People disclosing that a television presenter had visited a brothel and engaged in sexual activities with three prostitutes. He considered that there could be no blanket rule guaranteeing a

${ }^{38}$ Hellewell v Chief Constable [1995] 1 WLR 804 at 807.

39 Goldsmith \& Khan v BCD [2011] EWHC 674; Inerman v Tchenguiz [2011] 1 All ER 555.

${ }^{40}$ YYZ v YVR [2011] EWHC 274.

${ }^{41}$ McKennitt $v$ Ash [2006] EWCA Civ 1714 (information about a music star obtained by an aide).

42 Douglas v Hello! Ltd (No 3) [2005] EWCA Civ 595; Mosley v News Group Newspapers Ltd [2008] EWHC 1777.

${ }^{43}$ Holden v Express Newspapers Ltd, June 7th 2001, Eady J (referred to by Ouseley J in Theakston v Mirror Group Newspapers Ltd. [2002] EWHC 137 at [41]); Campbell v Mirror Group Newspapers Ltd [2004] 2 AC 457 at [123]; Murray v Big Pictures (UK) Ltd [2008] EWCA Civ 446 at [50]; Von Hannover v Germany [2004] ECHR 294.

${ }^{44} D$ v L [2003] EWCA Civ 1169 at [24] and [34].

45 Campbell v Mirror Group Newspapers Ltd [2004] 2 AC 457 at [123]; Murray v Big Pictures (UK) Ltd [2008] EWCA Civ 446; [2009] Ch 481 at [50] and [57]. It is possible for different views to be held as to whether the element of harassment or stalking by paparazzi was an important ingredient in the decision in Von Hannover $v$ Germany [2004] ECHR 294: see Murray at [43]ix; compare JIH v News Group Newspapers Ltd, [2010] EWHC 2818 at [59].

${ }^{46}$ [2006] QB 125 at [83].

47 [2002] EWHC 137. 
presumption of privacy or confidentiality for sexual conduct. Shortly afterwards, the Court of Appeal held that it was not appropriate to grant anonymity to a premier league footballer who, despite being married with two children, had engaged in casual sexual relationships with a lap dancer and another woman, but did not want his wife to discover this. ${ }^{48}$

This robust view appears to have been displaced by a more protective attitude. In Mosley $v$ News Group Newspapers Ltd ${ }^{49}$ the News of the World published a report that the President of the Fédération Internationale de l'Automobile (the governing body for Formula 1 motor racing) had engaged in what it claimed was a "sick Nazi orgy with 5 hookers". The key issue was whether there was an expectation of privacy. Eady J's view was clear. He said that generalisations were best avoided:

"Nevertheless, one is usually on safe ground in concluding that anyone indulging in sexual activity is entitled to a degree of privacy especially if it is on private property and between consenting adults (paid or unpaid).,

It is hard to generalise about what other information which will be considered private. The location of the activity is not conclusive. In Von Hannover v Germany ${ }^{51}$ the European Court held that German magazines were wrong to publish paparazzi photographs showing Princess Caroline of Monaco engaging in ordinary activities in public places. She was not carrying out public duties and no other justification for the publication of the photographs had been made. Similar decisions have been made by English courts. ${ }^{52}$ Much depends upon the impact that publication will have. Lord Hope in Campbell v Mirror Group Newspapers Ltd suggested that where it is not obvious that information is private, "the broad test is whether disclosure of the information about the individual ("A") would give substantial offence to A, assuming that A was placed in similar circumstances and was a person of ordinary sensibilities., ${ }^{53}$ A relatively tough approach to this question was suggested in Ambrosiadou v Coward.$^{54}$ Lord Neuberger MR remarked:

\footnotetext{
${ }^{48} A$ v B \& C [2002] 1 FLR 1021.

49 [2008] EWHC 1777.

50 [2008] EWHC 1777 at [98].

51 [2004] ECHR 294.

52 Campbell v Mirror Group Newspapers Ltd [2004] 2 AC 457 at [123]; Murray v Big Pictures (UK) Ltd [2008] EWCA Civ 446.

53 Campbell v Mirror Group Newspapers Ltd [2004] UKHL 22 at [92].

${ }^{54}$ [2011] EWCA Civ 409.
} 
"While respect for family and private life is of fundamental importance, it seems to me that the courts should, in the absence of special facts, generally expect people to adopt a reasonably robust and realistic approach to living in the $21^{\text {st }}$ century.” ${ }^{55}$

\subsection{Publicity destroys Privacy?}

Under the old law of confidence, when information enters the public domain, the courts will not protect it further by injunction. ${ }^{56}$ The same principle has been applied to privacy, ${ }^{57}$ provided the information is generally available. $^{58}$ In the Mosley case, ${ }^{59}$ Eady J declined to grant an injunction requiring the News of World to remove a covertly taken video from its website because:
"the material is so widely accessible that an order in the terms sought would make very little practical difference. One may express this conclusion either by saying that $\mathrm{Mr}$ Mosley no longer has any reasonable expectation of privacy in respect of this now widely familiar material or that, even if he has, it has entered the public domain to the extent that there is, in practical terms, no longer anything which the law can protect. The dam has effectively burst.”60

Conversely, it has been said that "in the context of personal information (as opposed to commercial secrets) it does not necessarily follow, from the fact that something has been published, that further coverage cannot itself infringe a claimant's privacy." $"$ This could be especially true of photographs,

\footnotetext{
${ }^{55}$ [2011] EWCA Civ 409 at [30].

${ }^{56}$ Attorney-General v Guardian Newspapers (No 2) [1990] 1 AC 109 (the Spycatcher case). See also Attorney General v Blake [2000] UKHL 45, [2001] 1 AC 268 (secrecy no longer applied following revelations by the spy and traitor George Blake - State left to pursue remedies in damages or account of profits); British Broadcasting Corporation v HarperCollins Publishers Ltd [2010] EWHC 2424 (identity of "the Stig" no longer secret).

${ }^{57} X$ \& Y v Persons Unknown [2006] EWHC 2783 at [38].

${ }^{58}$ ETK v News Group Newspapers Ltd [2011] EWCA Civ 439 at [11]; Browne v Associated Newspapers Ltd [2007] EWCA Civ 295 at [61].

${ }^{59}$ [2008] EWHC 687 (hearing on damages [2008] EWHC 1777).

60 [2008] EWHC 687 at [36]. See also to the same effect ETK $v$ News Group Newspapers Ltd [2011] EWCA Civ 439 at [10].

${ }^{61} X$ \& Y v Persons Unknown [2006] EWHC 2783 at [64]; JIH $v$ News Group Newspapers Ltd [2010] EWHC 2818 at [59]; TSE v News Group Newspapers Ltd [2011] EWHC 1308].
} 
for instance images of "a film star ... photographed, with the aid of a telephoto lens, lying naked by her private swimming pool”. ${ }^{2}$

\subsection{Whose Privacy?}

It is not only the claimant's privacy that has to be considered. In $R e$ Guardian News and Media Ltd, HM Treasury v Ahmed, ${ }^{63}$ the main case made in argument for affording anonymity to a number of individuals suspected of involvement in terrorism was the impact upon relatives. The impact on children may be particularly relevant. ${ }^{64}$ In ETK $v$ News Group Newspapers $L t d,{ }^{65}$ although an affair between two journalists was an open secret amongst colleagues, the Court of Appeal refused to allow it to be made more widely known partly because of the impact of publicity on the man's children. Similarly, in $C C \vee A B,{ }^{66}$ the effect that disclosure would have on the claimant's wife, who was in a fragile mental state and was attempting to rebuild her marriage, was a reason for granting an injunction to prevent a cuckolded husband, in revenge, publishing the fact that his wife had had an affair with the claimant. Even where the court has not been asked to take account of the rights of a party, it can act on its own initiative if that person's Article 8 rights are engaged. In CDE v Mirror Group Newspapers Ltd, ${ }^{67}$ when granting an injunction to prevent revelations about a virtual sexual relationship involving a minor celebrity, Eady $\mathrm{J}$ was influenced by the impact that the contemplated coverage would have on the family of one of the others involved.

\section{THE NEW METHODOLOGY}

\subsection{A Question of Balance}

Before the HRA the debate about anonymity was conducted largely on the basis of the balance between the principles of open justice and of confidentiality. The balance is now principally between the rights to respect for privacy and family life under Article 8, and to freedom of expression under Article 10. The principle of open justice remains relevant even where

\footnotetext{
${ }^{62}$ Douglas v Hello! Ltd (No 3) [2006] QB 125 at [105].

63 [2010] UKSC 1.

64 See Murray v Big Picture (UK) Ltds [2008] EWCA Civ 446 (publication of photographs of son of JK Rowling) and Ivereigh $v$ Associated Newspapers Ltd [2008] EWHC 339 (anonymity agreed to protect family of witness in libel case).

65 [2011] EWCA Civ 439.

66 [2006] EWHC 3083.

67 [2010] EWHC 3308.
} 
no claim is made under Article 10. Neither the principles of confidentiality or of open justice nor rights under Articles 8 and 10 are absolute. There are, however, significant differences between the old and new approaches.

Before the HRA the starting point was the principle of open justice, attenuated only where necessary in the interests of justice. The case for anonymity had to be compelling. ${ }^{68}$ The HRA has resulted in what has been described as a "new methodology." whether Article 8 is engaged, and if so, whether the presumption that privacy should be protected is displaced by other considerations including those set out in Article 10. In $\operatorname{Re} \mathrm{S}$ (A Child) (Identification: Restrictions on Publication) Lord Steyn identified four propositions as emerging from Campbell v Mirror Group Newspapers $L t d^{70}$ where both articles 8 and 10 are engaged:

"First, neither article has as such precedence over the other. Secondly, where the values under the two articles are in conflict, an intense focus on the comparative importance of the specific rights being claimed in the individual case is necessary. Thirdly, the justifications for interfering with or restricting each right must be taken into account. Finally, the proportionality test must be applied to each. For convenience I will call this the ultimate balancing test." ${ }^{71}$

In $A M M v H X W$ Tugendhat $\mathrm{J}$ has said of this test that, "Having carried out the exercise prescribed by the Supreme Court in the two recent cases, the judge will either have a duty to make an anonymity order, or a duty not to make one... It is not a matter of the court's discretion." ${ }^{72}$

\subsection{Human Rights Act s12}

The government incorporated special provisions in to the HRA to address concerns about the potential impact on press freedom. ${ }^{73}$ Section 12 applies when a court is considering injunctions which may restrict freedom of expression. The section states that no relief is to be granted in ex parte proceedings unless all practicable steps have been taken to notify the respondent, or there are compelling reasons why the respondent should not be

\footnotetext{
${ }^{68}$ Scott v Scott [1913] AC 417.

69 By Lord Steyn in Re S (A Child) (Identification: Restrictions on Publication) [2005] 1 AC 593 at [23].

70 [2004] AC 457.

71 [2004] UKHL 47; [2005] 1 AC 593 at [17].

72 [2010] EWHC 2457 at [34]-[35].

${ }^{73}$ See the Neuberger Report para 1.5.
} 
notified. It also requires the court to "have particular regard to the importance of the Convention right to freedom of expression" and in this context to the public interest, the extent to which information is in or is about to enter the public domain, and the provisions of any relevant privacy code. The section also provides that an injunction against publication before trial should not be granted "unless the court is satisfied that the applicant is likely to establish that publication should not be allowed."

In Cream Holdings Ltd $v$ Banerjee ${ }^{74}$ the Court of Appeal had concluded "that the more obvious meaning of the words in s12(3) is 'more likely than not to establish' (rather than 'has a real prospect of establishing')," ${ }^{75}$ but nevertheless felt constrained to conclude that the test was the lower one given the impact that a higher test "would have on competing Convention rights.", The House of Lords reversed the decision. Lord Nicholls, in an opinion with which the other Lords agreed, said:

"the degree of likelihood of success at the trial needed to satisfy section 12(3) must depend on the circumstances. There can be no single, rigid standard governing all applications for interim restraint orders. Rather, on its proper construction the effect of section 12(3) is that the court is not to make an interim restraint order unless satisfied the applicant's prospects of success at the trial are sufficiently favourable to justify such an order being made in the particular circumstances of the case... the general approach should be that courts will be exceedingly slow to make interim restraint orders where the applicant has not satisfied the court he will probably ('more likely than not') succeed at the trial." 77

Lord Nicholls felt that this compromise was "Convention-compliant". ${ }^{78}$ Whether it defends the principle of freedom of expression in the way Parliament anticipated is another matter. The Neuberger Report notes that "there is reasonable and legitimate argument whether the courts have interpreted HRA s12 as Parliament intended."79

74 [2005] 1 AC 253.

75 [2003] Ch 650 at [58].

76 [2003] Ch 650 at [59].

${ }_{78}^{72}$ [2005] 1 AC 253 at [22].

78 [2005] 1 AC 253 at [23].

79 The Neuberger Report para 1.5. 


\subsection{Press Code of Practice}

Under the HRA s12(4), a court is required to have particular regard to "any relevant privacy code", when considering injunctions relating to (inter alia) journalistic material which might affect the Convention right to freedom of expression. The relevant code is the Press Complaints Commission Code of Practice. The guidance the Code provides follows closely the terms of the ECHR and the developing English caselaw. In part because of this close alignment, there have been very few cases in which the Code has added anything to the decision-making process. For instance, in $A \vee B \& C^{80}$ Lord Woolf, setting out guidelines for considering privacy cases, said that the Code "is only one of a number of factors to be taken into account". ${ }^{81}$ Likewise, in Campbell v Mirror Group Newspapers Ltd ${ }^{82}$ the Code was referred to by Baroness Hale as confirming the restoration by the House of Lords of the conclusion reached at first instance. This does not mean that the Code is unimportant, for there may be cases where the Code of Practice contains requirements going beyond those required by law. For instance the European Court considered in Mosley $v U K^{83}$ that it would be inappropriate to condemn the English legal system for the absence of a requirement to notify the individual concerned prior to publication of potentially private information, but that a pre-notification requirement subject to a public interest exception could sensibly be included in the Code of Practice. Moreover, as Brooke LJ said in Douglas v Hello! Ltd "A newspaper which flouts clause 3 of the code is likely in those circumstances to have its claim to an entitlement to freedom of expression trumped by article 10(2) considerations of privacy." ${ }^{84}$

\section{JUSTIFYING DISCLOSURE}

\subsection{Competing Individual Rights}

Where Articles 8 and 10 most evidently come into conflict is where two individuals involved in the same actions differ about making them public. In Theakston $v$ News Group Newspapers $L t d^{85}$ Ouseley J, considered that the right to freedom of expression of the prostitutes involved in a casual sexual encounter in a brothel outweighed the man's claim to privacy. $A \vee B \& C^{86}$

\footnotetext{
${ }^{80} A v B \& C$ [2003] QB 195.

81 [2003] QB 195at [11](xiv).

82 [2004] AC 457 at [159].

83 [2011] ECHR 774.

84 [2001] QB 967 at [94].

85 [2002] EWHC 137.

${ }^{86}$ [2003] QB 195.
} 
established that "the court will be less inclined to protect the rights of one party to a sexual relationship if the other party wishes to reveal what happened. ${ }^{, 87}$ Privacy seems to have ranked higher in more recent cases. ${ }^{88}$

\subsection{Public Interest}

The justification that publication would be in the public interest is surprisingly rarely argued in opposing privacy orders. ${ }^{89}$ This may be because the argument has rarely been successful. ${ }^{90}$ There is a dichotomy between public interest arguments presented to Court and those made in newspaper comments. Sir Fred Goodwin, the erstwhile chief executive of the Royal Bank of Scotland, obtained an injunction banning a report that at a critical time leading to the bank's collapse he had an affair with a female senior colleague. The order initially prevented even his occupation being mentioned because it might have led to his identification. A significant element in the campaign to lift the injunction was that the public had a right to know of the alleged affair in view of the public takeover of the bank and the possibility that the affair might in some way have contributed to the bank's problems. The argument does not appear to have been put to the Court. ${ }^{91}$

The sorts of situation which might give rise to a public interest justification are disclosure of activities which are in "breach of the country's security, ${ }^{92}$ or in breach of law, including statutory duty, fraud, or otherwise destructive of the country or its people, including matters medically dangerous to the public." ${ }^{93}$ Disclosing a misuse of corporate power would be of legitimate public interest. ${ }^{94}$ In Campbell v Mirror Group Newspapers Ltd ${ }^{95}$ the House of Lords apparently agreed with the concession made by Naomi Campbell that disclosure of her drug addiction was justified because it

${ }^{87}$ The proposition was accepted in those terms by Eady $\mathrm{J}$ in $C C v A B$ [2006] EWHC 3083 at [32].

${ }^{88}$ See the Imogen Thomas story below.

89 See TSE v News Group Newspapers Ltd [2011] EWHC 1308; Butterworth and Wolfe-Robinson, Guardian online August $5^{\text {th }} 2011$.

90 See the remark of Tugendhat J in TSE v News Group Newspapers Ltd [2011] EWHC 1308 at [11].

${ }^{91}$ MNB v News Group Newspapers Ltd [2011] EWHC 528 at [6] and [18]; Goodwin v News Group Newspapers Ltd [2011] EWHC 1309 at [9].

92 The Profumo scandal might be an example: see $C C v A B$ [2006] EWHC 3083 at [37].

${ }^{93}$ Beloff v Pressdram [1973] RPC 765 at 783.

94 See Browne v Associated Newspapers Ltd [2007] EWCA Civ 295; [2008] 1 QB 103 at [52]; Goodwin v News Group Newspapers Ltd [2011] EWHC 1341 [14].

95 [2004] 2 AC 457 at [36]. 
corrected earlier, incorrect statements that she had made that she had no drug problem. Exposing hypocrisy on the part of a politician whose personal life is at odds with public claims would probably be treated similarly. ${ }^{96}$

A key distinction, repeatedly made in the cases, is that what is of interest to the public is not necessarily of public interest. Entertaining the public is not enough. As Lady Hale said in a libel case, Jameel $v$ Wall Street Journal:

"there must be a real public interest in communicating and receiving the information. This is, as we all know, very different from saying that it is information that interests the public - the most vapid tittletattle about the activities of footballers' wives and girlfriends interests large sections of the public but no-one could claim any real public interest in our being told all about it." 97

In ETK $v$ News Group Newspapers Ltd ${ }^{98}$ Ward LJ considered that the decisive factor in assessing public interest "is the contribution the published information will make to a debate of general interest." ${ }^{\text {"99 }}$ It is hard to see how this advances an understanding of the public interest since debates of general interest frequently relate to "vapid tittle-tattle". Refusing to permit proposed revelations about a journalist's extra-marital affair which led to the sacking of a colleague, he set out other criteria:

"Here there is no political edge to the publication. The organisation of the economic, social and political life of the country, so crucial to democracy, is not enhanced by publication. The intellectual, artistic or personal development of members of society is not stunted by ignorance of the sexual frolics of figures known to the public." 100

\footnotetext{
${ }^{96}$ Francome v Mirror Group Newspapers Ltd [1984] 1 WLR 892, at p 989 per Sir John Donaldson MR; the argument would probably not succeed with a footballer or a musician who had not made direct claims to a squeaky clean personal life: see TSE $v$ News Group Newspapers Ltd [2011] EWHC 1308 at [11]; Lee v News Group Newspapers Ltd [2010] NIQB 106 at [46].

97 [2006] 2 AC 465 at [147]. The case has been cited as accurately stating the law in privacy cases: see $n 152$ below.

98 [2011] EWCA Civ 439.

99 See also Re Guardian News and Media Ltd [2010] UKSC 1. This formulation of the test is derived from the judgment of the European Court in Von Hannover $v$ Germany (2005) 40 EHRR 1.

100 [2011] EWCA Civ 439 at 10.
} 


\subsection{Wider Public Interest}

As was explained above, ${ }^{101}$ the principle of open justice is itself based upon the public interest. It has also been recognised that there is a public interest in having active news media, not just at the national level, but also in local publications. If newspapers are unable to print what interests the public, they will sell fewer copies, and this can jeopardise their viability. ${ }^{102}$ Such general arguments about the public interest will not suffice in justifying disclosure of private information.

Considerations of wider public interest have, however, influenced the courts (albeit only in a limited way) in their policy of allowing anonymised information about injunctions to be made public, rather than naming the claimant without explaining the reasons for the injunction. Lord Neuberger in $J I H v$ News Group Newspapers Ltd said that, when a restriction was required, the public interest was better served by the first of these two options. ${ }^{103}$

\subsection{Onus of Proving Public Interest}

The person claiming a public interest justification bears the onus of proof. $^{104}$ In the Goodwin case Tugendhat J did not accept that disclosure was justified by a possible breach of corporate governance rules at the Royal Bank of Scotland since no evidence was provided of those rules other than a print out of the group "Code of Conduct on Integrity Matters", and counsel admitted that direct enquiries had not been made of the parties involved or within the Bank. ${ }^{105}$

\section{PROPORTIONALITY}

\subsection{Interference must be Proportional}

The concept of proportionality has become a legal theme as significant in late $20^{\text {th }}$ and early $21^{\text {st }}$ century jurisprudence as the concept of reasonable forseeability was in the half century following Donoghue $v$ Stevenson. ${ }^{106}$ It is a key component in the balancing exercise between Articles 8 and 10. As Lord Neuberger said in his lecture on Privacy and Freedom of Expression:

\footnotetext{
${ }^{101}$ See $\S 1.2$ above.

${ }^{102}$ A v B \& C [2003] QB 195 at [11] (xii).

103 [2011] EWCA Civ 42 at [33]. See below §5.2.

104 Hutcheson (Formerly Known As "KGM") v News Group Newspapers Ltd [2011] EWCA Civ 808 at [31].

105 Goodwin v News Group Newspapers Ltd [2011] EWHC 1309 at [17]-[19].

106 [1932] AC 562,
} 
"When considering the conflict between the two the court is required to do three things: first, it must intensely scrutinise the comparative importance of the specific rights claimed in the particular case; it must then consider the justifications set out for interfering with or restricting each right; and finally, the court must consider the proportionality of the proposed interference or restriction.” 107

Since at least $J I H v$ News Group Newsapapers $L t d^{108}$, in which guidelines were laid down by the Court of Appeal, the courts have enunciated the principle that "restrictions on reporting should always be kept to a minimum," ${ }^{\prime 109}$ although press commentary disputes that this has happened in practice.

\subsection{Tailoring the Remedy}

In most cases where disclosure of a sexual relationship has been permitted, the disclosure allowed has been confined to the fact of the relationship, with the omission of the salacious details (like the famous but probably untrue account of David Mellor wearing his Chelsea United kit for a sexual encounter ${ }^{110}$ ) that often characterised pre HRA accounts. ${ }^{111}$ Tugendhat J pointed out in Gray $v$ UVW that:

"There is a range of measures open to the court to protect the Article 8 rights of the parties. These include a variety of measures to prohibit or prevent disclosure of the information sought to be protected, and an order prohibiting disclosure of the identity of one or both parties. But each measure is cumulative. The fact that one such measure may be necessary is not a reason for concluding that they are all necessary. On the contrary, the measures as a whole must be no more than is necessary and proportionate, and if one measure is adopted, then that may mean that an additional measure is not necessary."

107 Privacy and Freedom of Expression: A Delicate Balance, lecture by Lord Neuberger at Eton, April $28^{\text {th }} 2010$.

108 JIH v News Group Newspapers Ltd [2011] EWCA Civ 42.

${ }^{109}$ Ibid at [29].

${ }^{110}$ A story which featured on the front page of the The Sun in July 1992.

111 Theakston v Mirror Group Newspapers Ltd [2002] EWHC 137 at [75]; John Terry (previously referred to as LNS) v Persons Unknown [2010] EWHC 119.

112 [2010] EWHC 2367 at [56]. 
Hirschfeld $v$ McGrath ${ }^{113}$ offers an example of a tailored remedy. The defendant was proposing to write an autobiography that his ex-wife feared would contain private information about her health and other matters during their married life. The original anonymised injunction was amended to name the parties following the hearing on the return date because it was acknowledged that since the husband gave undertakings not to make the disclosures, there was no longer a need for anonymity.

\subsection{The Extent of the Intrusion}

A crucial consideration is the extent of the intrusion into privacy. The publication of photographs is seen as considerably more intrusive ${ }^{114}$ and much less likely to be permitted than publication of an account in words. ${ }^{115}$ In Callaghan $v$ Independent News \& Media $\operatorname{Ltd}^{116}$ a convicted sexual murderer objected to the publication of photographs, taken in a cafe and a shopping centre, that might help to identify him. The Northern Ireland High Court granted the injunction, although his name, his age, and details of his crime could still be published. ${ }^{117}$

\subsection{Truth or Falsity}

Unlike the law of defamation, which is concerned with the publication of falsehoods, the protection of private and family life applies whether or not allegations are true. This was resolved in McKennitt $v$ Ash ${ }^{118}$. The Court of Appeal held that "the defendant cannot deprive the claimant of his Article 8 protection simply by demonstrating that the matter is untrue". ${ }^{119}$ Eady $\mathrm{J}$ explained in CTB $v$ News Group Newspapers Ltd:

\footnotetext{
113 [2011] EWHC 249.

114 Douglas \& Ors v Hello! Ltd (No 3) [2006] QB 125 at [84]; Von Hannover $v$ Germany 40 EHRR 1 at [59].

${ }^{115}$ Campbell v Mirror Group Newspapers Ltd [2004] 2 AC 457; Theakston v Mirror Group Newspapers Ltd [2002] EWHC 137; Amanda Holden v Express Newspapers Ltd (June 7th 2001).

116 [2009] NIQB 1.

117 Callaghan v Independent News \& Media Ltd [2009] NIQB 1. Compare Murray v Newsgroup Newspapers Ltds [2010] IEHC 248 in the Republic of Ireland, where Callaghan was distinguished, and a different decision reached.

118 [2006] EWCA Civ 778.

119 McKennitt $v$ Ash [2006] EWCA Civ 1714. See also AMM v HXW [2010] EWHC 2457 at [14]. Doubts about the availability of an injunction in similar circumstances had been expressed by Tugendhat J in RST v UVW [2009] EWHC 2448.
} 
"It is important always to remember that the modern law of privacy is not concerned solely with information or "secrets": it is also concerned importantly with intrusion." 120

The falsity of a statement may be relevant in weighing the balance between Articles 8 and 10. As was said in McKennitt $v$ Ash ${ }^{121}$, the falsity of allegations will undermine a public interest justification. Untrue allegations may also increase the degree of intrusion into privacy since a failure to refute the allegations could be seen as acknowledging their truth. ${ }^{122} \mathrm{~A}$ false public interest claim, like the incorrect assertion in the Mosley case that there was a Nazi theme to a sado-masochistic sex party, ${ }^{123}$ may also "rub salt into the wound," and be reflected in the award of damages.

Tugendhat $\mathrm{J}$ had little hesition in ZAM $v C F W^{125}$ in granting an injunction to prevent the dissemination of libellous allegations of misappropriation of funds from family trusts, which, if unchecked, would have constituted harassment. Although he accepted that it was unusual to grant injunction to to prevent the making of defamatory statements, the defendants had made no representations suggesting that any defence could be provided that would succeed at trial. ${ }^{126}$

\subsection{Blackmail}

In some "kiss and tell" cases, the person seeking publicity for their story has first contacted the celebrity involved seeking payment with the implicit or explicit threat or understanding that publication will follow if they do not comply. ${ }^{127}$ In Theakston v Mirror Group Newspapers Ltd, Ouseley J was only prepared to block publication of information obtained specifically for the purpose of blackmail, and not other information. ${ }^{128}$ Other cases have not made the same distinction. ${ }^{129} A M M v H X W^{130}$ the ex-wife of a television presenter

\footnotetext{
${ }^{120}$ [2011] EWHC 1326 at [78].

121 [2008] QB 73 at [79].

122 XJA v News Group Newspapers Ltd [2010] EWHC 3174 at [8].

123 See Cathcart, Code Breakers, Index on Censorship, June 30 2011.

124 Mosley v News Group Newspapers Ltd [2008] EWHC 2341 at [29]; [2008] EWHC 1777 at [222].

${ }_{125}^{125}$ [2011] EWHC 476.

126 Citing Bonnard v Perryman [1891] 2 Ch 269 and Greene $v$ Associated Newspapers Ltd [2005] QB 972.

${ }^{127}$ See Ntuli v Donald [2011] 1 WLR 294; Theakston v Mirror Group Newspapers Ltd. [2002] EWHC 137.

${ }^{128}$ [2002] EWHC 137 at [70] and [80].

${ }^{129}$ For example DFT v TFD [2010] EWHC 2335.
} 
was proposing to disclose information about their relationship including an alleged affair after their divorce. It is very unlikely that any of the information was acquired for the purpose of blackmail. Tugendhat $\mathrm{J}$ considered that "The fact that a person is making unwarranted demands with threats to disclose information does not of itself mean that that person has no right to freedom of expression." 131 There might even be cases where the blackmailer was under a duty to disclose the information. However:

"if a person is making unwarranted demands with threats to publish, that is a factor in deciding whether that person has any Art 10 rights, and, if so, then the weight to be accorded to them in balancing them with the applicant's Art 8 rights. In my judgment, the need to have regard to the Art 8 rights of the Claimant, and to promote the public interest in preventing and punishing blackmail are both factors which weigh strongly in favour of the grant of an anonymity order."132

In the same way, the fact that information has been obtained by manipulation, subterfuge or pressure is likely to be a factor in any assessment of proportionality. ${ }^{133}$

\subsection{Courting Publicity}

Well before the HRA, Bridge LJ said in Woodward v Hutchin:

"It seems to me that those who seek and welcome publicity of every kind bearing upon their private lives so long as it shows them in a favourable light are in no position to complain of the invasion of their privacy by publicity that shows them in an unfavourable light.” 134

This view has been repeated since the HRA came into force. In $A v B \& C$ Lord Woolf said: "If you have courted public attention then you have less ground to object to the intrusion which follows." ${ }^{135}$ An identical view was

${ }^{130}$ [2010] EWHC 2457. Also applied in POI v The Person Known As Lina [2011] EWHC 25.

${ }_{131}$ [2010] EWHC 2457 at [38].

132 [2010] EWHC 2457 at [38]-[39]. Sharp J adopted the same logic in KJH $v$ HGF [2010] EWHC 3064 at [11].

${ }^{133}$ CDE v MGN Ltd [2010] EWHC 3308 at [40].

134 [1977] 1 WLR 760 at 765 (Lord Denning concurring).

135 [2003] QB 195 at [11]. See also Hutcheson (Formerly Known As "KGM") v News Group Newspapers Ltd [2011] EWCA Civ 808. 
taken in Murray $v$ Big Pictures (UK) Ltd ${ }^{136}$ where the issue concerned the right to privacy of the son of JK Rowling. The Court of Appeal accepted the view of the trial judge that:

"it is difficult to see how ... a famous parent who chooses to exploit his children to gain personal publicity could avoid publication of photographs taken of his children in a public place simply by resorting to the device of making that child the Claimant."137

In Hickey $v$ Sunday Newspapers $L t d^{138}$ the Irish High Court declined to grant damages for the publication of pictures of the plaintiff leaving the Registry Office with her child from a relationship with the husband of a wellknown performer called "Twink" "139, partly because the "plaintiff had spoken to a journalist with the specific intention of publicity being accorded to the very matters in respect of which she now seeks to claim privacy."140

\subsection{Public Figures}

The extent to which there is a reasonable expectation of privacy or a public interest in disclosure may be affected by a person's public profile. In $A$ $v B \& C^{141}$ Lord Woolf, in setting out guidelines for first instance judges to follow in privacy cases, referred to Council of Europe Resolution 1165 of 1998 which states:

"Public figures must recognise that the special position they occupy in society - in many cases by choice - automatically entails increased pressure on their privacy. ${ }^{142}$ Public figures are persons holding public office and/or using public resources and, more broadly speaking, all those who play a role in public life, whether in politics, the economy, the arts, the social sphere, sport or in any other domain."143

In this context Lord Woolf observed that:

\footnotetext{
136 2008] EWCA Civ 446.

137 [2008] EWCA Civ 446 at [15] and [38].

138 [2010] IEHC 349, [2011] 1 ILRM 333.

139 Also known as Adele King.

${ }^{140}$ [2010] IEHC 349 (the judgment does not contain numbered paragraphs).

141 [2003] QB 195.

142 Council of Europe Resolution 1165 of 1998 para 6.

${ }^{143}$ Council of Europe Resolution 1165 of 1998 para 7.
} 
"A public figure is entitled to a private life. The individual, however, should recognise that because of his public position he must expect and accept that his actions will be more closely scrutinised by the media. Even trivial facts relating to a public figure can be of great interest to readers and other observers of the media." ${ }^{444}$

This strongly suggests that the boundary between public and private life is drawn at a different place in respect of public figures. However, some subsequent cases have cast doubt on this. Lord Phillips MR in Campbell $v$ Mirror Group Newspapers Ltd said that:

"When Lord Woolf spoke of the public having 'an understandable and so a legitimate interest in being told' information, even including trivial facts, about a public figure, he was not speaking of private facts that a fair-minded person would consider it offensive to disclose." ${ }^{145}$

Lord Neuberger has gone further still (in the context of responding to newspapers suggesting that celebrities were benefiting from legal processes which would not be available to those with more limited means) in saying, "no special treatment should be accorded to public figures or celebrities: in principle, they are entitled to the same protection as others, no more and no less." 146

\subsection{Role Models}

Lord Woolf in $A \vee B$ \& $C$ observed that it was relevant that "Footballers are role models for young people and undesirable behaviour on their part can set an unfortunate example." ${ }^{, 147}$ Subsequent decisions appear to have distanced from this view. In McKennitt $v$ Ash ${ }^{148}$ Buxton LJ suggested that Lord Woolf's remarks on this point were directed principally at disreputable conduct (presumably because disclosure of disreputable conduct could be justified as in the public interest). Baroness Hale in Campbell $v$ Mirror Group Newspapers Ltd was even more emphatic, observing: "It might be questioned why, if a role model has adopted a stance which all would agree is beneficial rather than detrimental to society, it is so important to reveal that she has feet

\footnotetext{
${ }^{144} A v B \& C[2003]$ QB 195 at [11] (xii).

145 [2003] QB 633 at [40].

146 JIH V News Group Newspapers Ltd [2011] EWCA Civ 42 at [21](6).

147 [2003] QB 195 at [43] (vi).

${ }^{148}$ McKennitt v Ash [2006] EWCA Civ 1714 at [65].
} 
of clay." ${ }^{149}$ It does not appear even to have been argued in the more recent cases involving footballers that their position as role models justifies a more intense focus on their behaviour or a more restricted view of what could reasonably be considered to be private.

\section{THE IMOGEN THOMAS STORY}

\subsection{The Background to the Story}

The Imogen Thomas story was at the centre of a crisis in the relationship between the courts, parliament, and the media, and it illustrates many of the issues concerning superinjunctions and anonymity orders. It involved a "kiss and tell" relationship between two "celebrities", one an originally unidentified footballer with a wife and family, the other a former Big Brother contestant.

On April $14^{\text {th }} 2011$ a story appeared in The Sun reporting that Imogen Thomas had a sexual relationship with a Premier League footballer over a period of six months. His name was not revealed because of an agreement with a Sun journalist on April $13^{\text {th }}$ that his name would not be disclosed pending a court hearing the following day. In the afternoon of April $14^{\text {th }}$ Eady $\mathrm{J}$ granted an order prohibiting disclosure of the footballer's identity until a further hearing scheduled for the following week. Following that hearing, Eady J confirmed the anonymity order. ${ }^{150}$

\subsection{The Process applied}

Eady $\mathrm{J}$ applied the new methodology. The footballer and his family had a reasonable expectation of privacy. "In this case, as in so many others, there can be no doubt on that score. It is concerned with conduct of an intimate and sexual nature and, what is more, there has been no suggestion in this case that the relationship, for so long as it lasted, was conducted publicly." 151 Against this, no public interest argument had been made. It was argued that the information was already in the public domain, but Eady J said "When the matter was before me, I was not persuaded that there was by that time nothing left to protect in respect of which the claimant still had a reasonable expectation of privacy." 152

${ }^{149}$ Campbell v Mirror Group Newspapers Ltd [2004] UKHL 22 at [151] echoing the similar sentiment of Lord Phillips in the Court of Appeal [2003] QB 633 at [41].

${ }^{150}$ His judgment giving his reasons was not published until May $16^{\text {th }} 2011$, and further argument took place on issues discussed below in CTB $v$ News Group Newspapers Ltd [2011] EWHC 1232.

${ }^{151}$ CTB v News Group Newspapers Ltd [2011] EWHC 1232 at [23].

${ }^{152}$ CTB v News Group Newspapers Ltd [2011] EWHC 1232 at [30]. 
Eady $\mathrm{J}$ then took into the balance the rights of Imogen Thomas and of the journalists to exercise their freedom of expression rights by selling and publishing the story. He said:

"It will rarely be the case that the privacy rights of an individual or of his family will have to yield in priority to another's right to publish what has been described in the House of Lords as "tittle-tattle about the activities of footballers' wives and girlfriends": see eg Jameel $v$ Wall Street Journal Europe SPRL. ${ }^{153}$ It has recently been reemphasised by the Court in Strasbourg that the reporting of 'tawdry allegations about an individual's private life' does not attract the robust protection under Article 10 afforded to more serious journalism. In such cases, 'freedom of expression requires a more narrow interpretation’: Mosley $v$ UK. ${ }^{154,, 155}$

The case for an injunction was strengthened by evidence which, although denied by Imogen Thomas (who had engaged the publicist Max Clifford to help her exploit her story), suggested a crude attempt at both blackmail and at a "set-up" hotel meeting to enable photographs to be taken. Counsel for the claimant told the judge that Ms Thomas had asked for $£ 50,000$, a sum which she later increased to $£ 100,000$, in return for keeping quiet. Eady J's view, on the evidence available to him, was that the applicant would be likely to obtain a perpetual injunction at a full trial, and it was therefore appropriate to continue the interim injunction. He made an order to that effect, with his judgment being handed down three weeks later.

\subsection{Footballer identified online}

Media interest in superinjunctions and anonymity orders became intense, with almost daily coverage in the print and broadcast media. A Twitter site (on a server located outside the UK) was created for subscribers to speculate as to which celebrities had obtained privacy orders. This case was one of the most popular, with a large majority correctly identifying the footballer. The footballer's response was reportedly twofold. First, on May $18^{\text {th }} 2011$ he commenced an action against Twitter seeking disclosure of the names of individuals who had posted his name on the site. ${ }^{156}$ Secondly, because lawyers

\footnotetext{
153 [2007] 1 AC 359 at [147].

154 [2011] ECHR 774, at [114].

155 CTB v News Group Newspapers Ltd [2011] EWHC 1232 at [34].

156 Josh Halliday, Guardian online, May 20 $0^{\text {th }}$ 2011. Twitter complied with a disclosure order brought in the US by a UK litigant complaining of libel (Sunday Telegraph May $29^{\text {th }}$ 2011).
} 
for the footballer suspected a leak from News Group Newspapers (NGN), publishers of The Sun, an application was made to Eady J for disclosure of email traffic and SMS messages by employees of the company, and by Kelvin MacKenzie, a journalist who wrote for The Sun, containing any reference to the claimant. Kelvin MacKenzie appears to have been named because he disclosed in a broadcast on BBC Radio on the morning of April $30^{\text {th }}$ that he regularly passed on the identities of claimants who had been granted injunctions, and that he sought to undermine anonymity orders by dropping "hints in his articles to give any interested readers a steer as to who might be covered by an order." ${ }^{~} 157$ Argument on this issue was heard on the same day as Eady J handed down his judgment on the continuation of the anonymity order. Eady $\mathrm{J}$ also heard argument from NGN that the growing information on the internet and in foreign publications meant that the identity of the footballer had so entered the public domain that to maintain the injunction would leave the court looking like King Canute seeking to hold back the tides. ${ }^{158}$

\subsection{Further developments}

Events then started to move more rapidly. At the end of the week in which Eady J heard argument, Lord Neuberger MR published his long-awaited report on superinjunctions. This did nothing to suppress media disquiet about the growing use of "gagging orders", and indeed may have increased concern since the press conference in which the report was made public appeared to be setting the judges and parliament on a potential collision course. Over the same weekend on $22^{\text {nd }}$ May, the Sunday Herald, a newspaper which circulates only in Scotland, published a full front page picture of the footballer with only his eyes obscured and an editorial saying that it was "unsustainable" for newspapers not to be able to print information widely available on the internet, adding "The issue is one of freedom of information and of a growing argument in favour of more restrictive privacy laws." The newspaper had received legal advice that the English Courts' injunction did not apply in Scotland.

The following day the Prime Minister confessed on ITV's daybreak programme, that "like everybody else" he knew the identity of the footballer, and added, echoing the concerns expressed by the Sunday Herald:

157 See CTB v News Group Newspapers Ltd [2011] EWHC 1326 (May 23 ${ }^{\text {rd }}$ 2011); [2011] EWHC 1232 (hearing on May 16th) at [8].

${ }^{158}$ See also CTB v News Group Newspapers Ltd [2011] EWHC 1326 at [18] and [24]. One version of this myth has it that Canute was in fact seeking to demonstrate to his subjects his powerlessness over nature rather than seeking to assert his omnipotence. 
"It is rather unsustainable, this situation, where newspapers can't print something that clearly everybody else is talking about, but there's a difficulty here because the law is the law and the judges must interpret what the law is. What I've said in the past is, the danger is that judgments are effectively writing a new law which is what Parliament is meant to do. So I think the Government, Parliament has got to take some time out, have a proper look at this, have a think about what we can do, but I'm not sure there is going to be a simple answer."

Later that morning, Eady $\mathrm{J}$ delivered his judgment on the arguments he had heard the previous week. He rejected the claim for disclosure of email and SMS traffic from Kelvin MacKenzie and NGN employees on the basis that the purpose of this disclosure was to demonstrate a contempt of court, and it was for the Law Officers of the Crown to take the initiative on this, with the court being slow to order the release of information which might result in selfincrimination. He also rejected the argument that the ban on naming the footballer should be lifted because his name was so freely available on the internet. In his view the purpose of an injunction protecting private life was not just to preserve confidentiality or secrecy, but to prevent intrusion, and each new publication constituted a further intrusion:

"In these circumstances, it seems to me that the right question for me to ask, in the light of $J I H v$ News Group Newspapers Ltd ${ }^{159}$ and Re Guardian News and Media Ltd, ${ }^{160}$ is whether there is a solid reason why the Claimant's identity should be generally revealed in the national media, such as to outweigh the legitimate interests of himself and his family in maintaining anonymity. The answer is as yet in the negative. They would be engulfed in a cruel and destructive media frenzy. Sadly, that may become unavoidable in the society in which we now live but, for the moment, in so far as I am being asked to sanction it, I decline to do so."161

\subsection{Footballer named in Parliament}

Eady J's prophecy was very rapidly fulfilled. The same day, on Monday May $23^{\text {rd }} 2011$, in a House of Commons debate, John Hemming MP named Ryan Giggs as the footballer concerned, before being called to order by the Speaker who insisted that Parliamentary Questions should be used as an opportunity for raising issues of principle rather than for flouting court orders.

${ }^{159}$ [2011] 2 All ER 324.

160 [2010] UKSC 1.

${ }^{161}$ CTB v News Group Newspapers Ltd [2011] EWHC 1326 at [26]. 
By this stage, of course, the cat was out of the bag, and the identity of Ryan Giggs was broadcast prominently on all the main television channels.

Finally that evening, NGN applied to have the anonymity order lifted because there remained no secrecy to protect. This was also rejected. Tugendhat J said:

"It is obvious that if the purpose of this injunction were to preserve a secret, it would have failed in its purpose. But in so far as its purpose is to prevent intrusion or harassment, it has not failed. The fact that tens of thousands of people have named the claimant on the internet confirms that the claimant and his family need protection from intrusion into their private and family life. The fact that a question has been asked in Parliament seems to me to increase, and not to diminish the strength of his case that he and his family need that protection. The order has not protected the claimant and his family from taunting on the internet. It is still effective to protect them from taunting and other intrusion and harassment in the print media."162

\subsection{Later revelations}

The futility of protecting Ryan Giggs by means of an injunction became more apparent as time passed. Newspaper stories revealed that as well as the affair with Imogen Thomas, Ryan Giggs had also conducted an affair with the fiancée of his younger brother Rhodri and with a third woman. The affair with the unnamed "third woman" lasted for two years, ending on his marriage; the affair with his brother's fiancée ended only on her wedding day. ${ }^{163}$ Reports said that only weeks previously, she was paid $£ 500$ by Ryan Giggs to abort his child. ${ }^{164}$

\section{COMMENTARY ON THE CURRENT POSITION}

\subsection{The press and the Courts}

Newspapers, both broadsheet and tabloid, have found privacy orders irksome, and have campaigned against them, principally through the pages of their newspapers rather than through the courts. For instance, in MJN v News

\footnotetext{
${ }^{162}$ CTB v News Group Newspapers Ltd [2011] EWHC 1334. He is also reported as saying "If a court can stop one person or five people.... - not 50,000 - is there not something to be achieved?": Josh Halliday and Ben Quinn, Guardian online, May $23^{\text {rd }} 2011$.

163 Daily Telegraph June 8th 2011; Daily Mail June 8th 2011.

${ }^{164}$ Greenhill and Narain, Mail online, June 13th 2011.
} 
Group Newspapers Ltd ${ }^{165}$ Kimberley West, a lingerie model, sold to The Sun the story of her relationship with a married premier league footballer. The newspaper conceded that an injunction should be granted, but then ran headlines complaining that the story had been "gagged". As has been seen, many other injunctions have been unopposed, ${ }^{166}$ and the public interest argument in publication is rarely put forward. ${ }^{167}$ This may be because the press does not consider it worthwhile ${ }^{168}$ or because it is using spurious claims about public interest to grandstand for the sake of good headlines.

There has been judicial comment on inaccurate reporting, ${ }^{169}$ but the relationship between the press and the judiciary may not have been helped by some of the fine distinctions made by judges. For instance, in Goodwin $v$ News Group Newspapers $L t d^{170}$ Tugendhat J claimed that the case had not involved a superinjunction because the existence of the order could be disclosed, even though disclosure was confined to saying "the Claimant was wealthy and married; and that he was a senior business executive."171 The court order prohibited disclosure of Sir Fred Goodwin's name or occupation, the name of the woman with whom he allegedly had an affair, or the fact that there had been a sexual relationship. The difference between this and a superinjunction as now defined in the Neuberger Report ${ }^{172}$ is surely so narrow that it is a question of semantics more than substance.

165 [2011] EWHC 1192.

166 See, for example, MNB (later identified as Goodwin) v News Group Newspapers Ltd [2011] EWHC 528; MJN v News Group Newspapers Ltd [2011] EWHC 1192.

${ }^{167}$ See Butterworth and Wolfe-Robinson, Guardian online, August $5^{\text {th }} 2011$.

168 Especially since the failure of the claim in Mosley $v$ News Group Newspapers [2008] EWHC 1777 that an unproved Nazi theme justified disclosure of the events at a sado-masochistic sex party.

169 See Goodwin v News Group Newspapers Ltd [2011] EWHC 1309; Goodwin v News Group Newspapers Ltd [2011] EWHC 1341 at [17]. See also Rozenberg, $\mathrm{Mr}$ Justice Eady on Balancing Acts, Index on Censorship, June 12 2011.

170 [2011] EWHC 1309.

171 MNB $v$ News Group Newspapers Ltd [2011] EWHC 528 at [17]. An order providing even less information than this was made in DFT v TFD [2010] EWHC 2335, but is described by Tugendhat $\mathrm{J}$ in AMM v HXW [2010] EWHC 2457 at [40] and in the Neuberger Report para 2.27 as being an anonymised injunction rather than a superinjunction.

172 See above, $\S 1.1$. 


\subsection{Judicial and Public Responses}

One of the first reactions of the judiciary to publicly expressed disquiet about superinjunctions was to put limits upon their use. In Ntuli $v$ Donald ${ }^{173}$ Maurice Kay LJ, delivering a judgment with which the other members of the court of appeal agreed, observed that "Superinjunctions attract understandable controversy." 174 He pointed out that a superinjunction was not necessary because Howard Donald could have been protected by a simple anonymity order or by a prohibition restraining the disclosure of details of the relationship. ${ }^{175}$ The same approach was adopted in JIH $v$ News Group Newspapers $\operatorname{Ltd}^{176}$ where, after laying out guidelines governing the use of superinjunctions or anonymity orders, Lord Neuberger accepted as a general proposition that anonymising the order or banning indentification of the confidential information were alternatives. ${ }^{177}$ Most injunctions since then, as the Neuberger Report indicates, have been anonymity orders rather than superinjunctions. Whilst this policy gives greater recognition to the values of open justice than would the use of superinjunctions, it may have had an unintended (although not unforeseen ${ }^{178}$ ) effect of fuelling speculation about the identity of the anonymised person involved. Whilst in years gone by that speculation might have taken place principally in parlours and public houses, it can now "go viral" over the internet. The speculation is not always accurate. On May $6^{\text {th }} 2011$ the Daily Mail reported that:

"mother-of-two Mrs Logan became a victim of the privacy row after a judge granted an unprecedented worldwide gagging order to a married television star, permanently banning publication of pictures of him with a woman. Internet and Twitter gossips seized on the entirely false idea that the BBC sports presenter has had an affair with pundit and former England football captain Mr Shearer”.

Jemima Khan similarly felt obliged several days later ${ }^{179}$ to deny rumours on the Twitter website that she had obtained a superinjunction to prohibit

\footnotetext{
173 [2010] EWCA Civ 1276.

174 Ibid at [47].

175 Ibid at [46].

${ }^{176}$ [2011] EWCA Civ 42.

${ }^{177}$ [2010] EWHC 2818 at [8] and [9].

178 JIH v News Group Newspapers Ltd [2011] EWCA Civ 42 at [38]: “An anonymity order runs the risk of unintentionally encouraging suspicion and gossip in relation to innocent third parties."

${ }^{179}$ Swinford, Telegraph online May $8^{\text {th }} 2011$.
} 
publication of intimate pictures of herself and Jeremy Clarkson, the Top Gear presenter.

Speculation about the names of stars who have obtained superinjunctions has become almost a sport in itself. Within two minutes of a Twitter account being set up to name the celebrities who had secured superinjunctions, "more than 2,000 people had signed up to follow updates and new postings." Within days "the account had more than 26,000 followers."

\subsection{Disdain in Parliament}

Concerns have been expressed in Parliament about the use of anonymity orders, and advantage has been taken of Parliamentary privilege to name two claimants, Sir Fred Goodwin and Ryan Giggs. John Hemming MP, who named Ryan Giggs, said that he did so because he wanted to protect his constituents and others from legal process for having named him on the internet:

"Basically when he... showed that he was going to go after relatively normal people and try and prosecute them, for gossiping about him on a matter of trivia, I think he has to be held to account for that.” ${ }^{181}$

The use of Parliamentary privilege in this way invoked the intervention of Mr Speaker, and adverse comment by senior judges. On the day that Ryan Giggs was named in Parliament, Lord Judge LCJ and Lord Neuberger were holding a press conference launching the Neuberger Report on Superinjunctions. ${ }^{182}$ Lord Judge said that the media:

"need to think whether it's a very good idea for our lawmakers to be in effect flouting a court order because they disagree with the order or, for that matter, because they disagree with the law of privacy which parliament has created", ${ }^{183}$

This remark was widely viewed as putting the courts and parliament on course for a constitutional crisis. ${ }^{184}$ Fortunately that prospect has not materialised, and the Neuberger Report itself takes a more measured view:

\footnotetext{
180 Swinford, Telegraph online May $9^{\text {th }} 2011$.

${ }^{181}$ BBC online May $23^{\text {rd }} 2011$.

182 See above $\$ 1.1$.

183 Bowcott and Watt, Guardian online, May $21^{\text {st }} 2011$.

${ }^{184}$ Sedley, The Goodwin and Giggs Show, (2011) 33 London Review of Books No. 12 p 3.
} 
"Article 9 of the Bill of Rights 1689 recognises and enshrines a longstanding privilege of Parliament: freedom of speech and debate. It is an absolute privilege and is of the highest constitutional importance. Any attempt by the courts to go beyond that constitutional boundary would be unconstitutional. No super-injunction, or any other court order, could conceivably restrict or prohibit Parliamentary debate or proceedings.”

That view has been accepted in Parliament by the Attorney-General as the considered and official response of the judiciary. ${ }^{185}$

\subsection{Enforcing Injunctions}

Anonymity orders are enforced in exactly the same way as other injunctions, namely, by the machinery of contempt of court. As orders granting injunctions make clear, disregarding the injunction can lead to a fine or imprisonment. The courts have, however, been reluctant to take the initiative. In responding to complaints that an anonymity order has been disregarded, judges have said that invoking the contempt of court process is a matter for the Attorney-General. In Goodwin v News Group Newspapers Ltd Tugendhat $\mathrm{J}$ declined to refer to the Attorney-General a complaint by the woman alleged to have had an affair with Sir Fred that press coverage had breached the injunction by tending to identify her:

"The reason that I decline to make the reference is that in my judgment it would not assist the Attorney-General. The lady is free to refer the matter to the Attorney-General herself, and the AttorneyGeneral is free to act of his own motion. This case has received extensive coverage in very many newspapers and other news media, and has been the subject of public judgments.” ${ }^{186}$

The Attorney-General said in Law in Action on BBC Radio 4 on June $7^{\text {th }}$ that "I will take action if I think that my intervention is necessary, in the public interest, to maintain the rule of law, proportionate, and would achieve an end of upholding the rule of law," and "the fact you are doing it on Twitter does not give some blanket exemption." He added that there was nothing to prevent litigants acting of their own initiative.

The rule of law depends not just upon the machinery of justice, however, but upon general compliance with the law. Where the law departs from what most individuals and the press perceive as being fair and appropriate, there is

${ }^{185}$ Commons Hansard May $23^{\text {rd }} 2011$ col 636.

${ }^{186}$ [2011] EWHC 1341 at [20]. 
a problem. If that problem persists, it can be dealt with only by a change in practice or by a change in the law.

\subsection{Speed and extent of development of privacy laws}

Britain's privacy laws underwent a metamorphosis with the enactment of the HRA 1998. There is no doubt that a fundamental and rapid change was required if Britain was to be compliant with the ECHR and the jurisprudence of the European Court. What is less clear is whether the extent of the change was necessary. Max Mosley's claim that his rights had been infringed because there was no requirement of pre-notification failed in the European Court. ${ }^{187}$ The Court considered that States had a wide "margin of appreciation" in meeting Convention obligations, especially under Article 8, since there was a lack of clarity about the notion of "respect" for private life; ${ }^{188}$ there were variations in practice across the Member States; ${ }^{189}$ the degree of protection for privacy needed to be commensurate with the seriousness of the invasion; ${ }^{190}$ and a fair balance had to be struck between the competing rights and interests arising under Articles 8 and $10 .{ }^{191}$ On the specific issue of Max Mosley's application, the view of the European Court was that the UK's practice in not requiring pre-notification was within the margin of appreciation. This was emphasised by the diversity of practice amongst member States about how to balance Articles 8 and $10,{ }^{192}$ and by the "not unjustified" concerns about the effectiveness of the duty given the need for a public interest exception, and the lack of means of enforcement which did not unduly "chill" freedom of

expression. ${ }^{193}$ More generally, the case suggests that a slower pace of development of privacy law, and a less aggressive approach to enforcement by means of prior restraint with greater reliance upon an effective system for payment of compensation for unjustified invasions of privacy might have been considered by the European Court to have been compliant with the Convention.

\footnotetext{
${ }^{187}$ Mosley v UK [2011] ECHR 774. See above, text to n 83.

188 [2011] ECHR 774 at [108].

189 [2011] ECHR 774 at [110].

190 [2011] ECHR 774 at [109].

191 [2011] ECHR 774 at [111].

192 [2011] ECHR 774 at [124].

193 [2011] ECHR 774 at [126].
} 


\subsection{Prior restraints require "most careful scrutiny”}

The European Court in Mosley appeared to have a particular concern about the use of prior restraint for dealing with invasions of privacy. The Court observed that:

"while Article 10 does not prohibit the imposition of prior restraints on publication, the dangers inherent in prior restraints are such that they call for the most careful scrutiny on the part of the Court. This is especially so as far as the press is concerned, for news is a perishable commodity and to delay its publication, even for a short period, may well deprive it of all its value and interest.” ${ }^{194}$

Whilst not a condemnation of the practice of granting injunctions to protect privacy, this is hardly a ringing endorsement of the current practice in England.

There are other considerations which suggest that the courts could have been less ready than they have to use anonymity orders so willingly in cases where the intrusion on private life does not have serious consequences. According to Lord Nicholls in Cream Holdings Limited $v$ Banerjee HRA section 12(3) was intended to inhibit the too ready grant of interlocutory injunctions by requiring a higher threshold for the grant of interlocutory injunctions against the media than the normal test. ${ }^{195}$ The provision has not had the impact which Parliament seems to have intended. ${ }^{196}$ In addition, the award of an interlocutory injunction is discretionary. The courts could have been less willing to find that respect for privacy automatically requires the grant of an injunction. More account could have been taken of the seriousness of the damage that a revelation would cause, and the real origin of that damage. If a footballer has been having an affair with his brother's fiancée would any damage to his marriage be the result of the footballer's infidelity (which his wife may have discovered anyway), of the lack of honesty in the relationship, or only of the publicity resulting from press coverage? The courts have traditionally been more cautious in granting injunctions in libel cases, as reflected in the rule in Bonnard $v$ Perryman $^{197}$ (an interlocutory injunction will not be granted where the defendant intends to prove the truth of the defamatory statement), and it is odd that a person should be more protected against the disclosure of the truth than against the telling of lies. Neither does the recent approach recognise the importance historically

194 [2011] ECHR 774 at [117].

195 2005] 1 AC 253 at [15].

196 See above $\$ 3.2$.

197 [1891] 2 Ch 269. 
accorded to freedom of expression. For instance, before the HRA, Hoffman $\mathrm{LJ}$ said of freedom of expression under the ECHR:

"It cannot be too strongly emphasised that outside the established exceptions, or any new ones which Parliament may enact in accordance with its obligations under the Convention, there is no question of balancing freedom of speech against other interests. It is a trump card which always wins." 198

Similarly, in $R \vee$ Shayler ${ }^{199}$ Lord Hope said that when looking at any restriction on freedom of expression, "A close and penetrating examination of the factual justification for the restriction is needed." Whilst these remarks were not made in the context of the balancing of Articles 8 and 10, they are illustrative of the importance of freedom of expression. The approach in Ireland, while applying principles very similar to those in England, appears to have a stronger bias against prior restraint. In Murray $v$ Newsgroup Newspapers $L t d^{200}$ a convicted violent sex offender objected to the disclosure of information which might have helped in his identification. Irvine J pointed out that particular care had to be taken where the relief being sought was a prior restraint order, ${ }^{201}$ and that, "any such restriction [on freedom of expression] calls for the most careful scrutiny," ${ }^{202}$ with the onus being on the plaintiff to demonstrate that it was required on the balance of convenience. ${ }^{203}$ The plaintiff's claim for an injunction failed because he had "failed to demonstrate sufficient significant inconvenience such as would justify a curtailment on the freedom of expression of the defendant newspapers." ${ }^{204}$

\subsection{Are the Restraints discriminatory?}

Tugendhat $\mathrm{J}$ has refuted suggestions that the operation of anonymised injunctions has been discriminatory. He said "there is no stereotype which can be used to categorise claimants in privacy actions, and many of them are

\footnotetext{
${ }^{198} R$ v Central Independent Television plc [1994] Fam. 192.

199 [2002] UKHL 11, [2003] 1 AC 247 at [61].

200 [2010] IEHC 248.

201 [2010] IEHC 248 at [58].

202 [2010] IEHC 248 at [109]. This proposition was derived from The Observer and the Guardian v U K (1992) 14 EHRR 153 where the European Court held that "Article 10 of the Convention does not in terms prohibit the imposition of prior restraints on publication, as such. ... On the other hand, the dangers inherent in prior restraints are such that they call for the most careful scrutiny by the Court.”

203 [2010] IEHC 248 at [85].

204 [2010] IEHC 248 at [85].
} 
women”. ${ }^{205}$ After giving a list of examples drawn from his book on privacy, he continued "All of the claimants in that passage were women or children, some rich, and some not rich.,"206 While this may be true, privacy orders are not cheap, with the cost certainly running to several thousand pounds, putting them beyond the reach of most people with ordinary means. In relation to gender, whilst there is no evidence of an inherent bias in the law, some of the most prominent reports have disclosed only the woman's side of a "kiss and tell” story, on occasions with details affecting her family. ${ }^{207}$

\subsection{Protecting Commercial Interests}

The European Court indicated in Von Hannover $v$ Germany that "the guarantee afforded by Article 8 of the ECHR is primarily intended to ensure the development, without outside interference, of the personality of each individual in his relations with other human beings." ${ }^{208}$ English law protects privacy even where the primary motive is commercial, ${ }^{209}$ and this has been a cause of some public disquiet. It is now probably too late for English law to distinguish between genuinely private space and space to which access is controlled for commercial reasons. However, the distinction is surely relevant when considering whether an injunction should be granted. Damages are far more likely to be an adequate remedy where privacy laws are being used to secure the opportunity for commercial exploitation than where privacy is being sought "to ensure the development of the personality".

\subsection{Ownership of the law}

England's new privacy law has been created by a combination of the legislative incorporation of the ECHR into English law; judicial development by English judges; and judicial development by the European Court. This interaction has not always been acknowledged. Some comments depict the law as having been imposed by Europe $\mathrm{e}^{210}$ or as being developed in a way which was not anticipated or authorised by Parliament. The Prime Minister,

\footnotetext{
${ }^{205}$ TSE v News Group Newspapers Ltd [2011] EWHC 1308 at [36].

206 TSE v News Group Newspapers Ltd [2011] EWHC 1308 at [38].

${ }^{207}$ For example NEJ $v$ Wood [2011] EWHC 1972 concerned the relationship between "a married actor" and Helen Wood, a woman reportedly previously involved in sex for payment with Wayne Rooney. Media reports contained information in relation to which Helen Wood's family might have had a reasonable expectation of privacy: Greenhill and Narain, Mail online, April 14th 2011.

${ }^{208}$ Von Hannover v Germany [2004] ECHR 294.

${ }^{209}$ Douglas v Hello! Ltd (No 3) [2005] EWCA Civ 595.

210 See Sir William Cash, Commons Hansard May 23 2011 Column 638.
} 
David Cameron, has said that "The judges are creating a sort of privacy law," ${ }^{211}$ about which he felt uneasy since Parliament, not judges, should decide on the balance between press freedom and privacy. Paul Dacre, writing in The Guardian, has gone even further. He said:

"The British press is having a privacy law imposed on it, which - apart from allowing the corrupt and the crooked to sleep easily in their beds - is undermining the ability of mass-circulation newspapers to sell newspapers in an ever more difficult market. This law is not coming from Parliament - no, that would smack of democracy - but from the arrogant and amoral judgments - words I use very deliberately - of one man. Justice David Eady has, again and again, under the privacy clause of the Human Rights Act, found against newspapers and their age-old freedom to expose the moral shortcomings of those in high places.",212

Conversely, other remarks suggest that the development of the law should have been no surprise to Parliament. The Neuberger Report states that "the courts (as Parliament anticipated) have developed the common law in light of the Convention and its jurisprudence," ${ }^{213}$ and the Attorney-General, in a Commons debate, remarked: "In constructing the Human Rights Act, I do not think Parliament can be described as anything other than open-eyed as to what it intended to do about privacy law." ${ }^{214}$ In CTB $v$ News Group Newspapers Ltd Eady J said:

"it has for several years been repeatedly claimed in media reports that courts are 'introducing a law of privacy by the back door'. Yet the principles have long been open to scrutiny. They are readily apparent from the terms of the Human Rights Act, and indeed from the content of the European Convention itself... the law has been loyally applied by the courts in a wide variety of circumstances and exhaustively explained in numerous appellate judgments.” 215

Eady $\mathrm{J}$ also felt obliged to defend the development of the law in one of the hearings in the Mosley litigation:

\footnotetext{
211 Cameron 'uneasy' about use of injunctions, BBC online 21 April $21^{\text {st }} 2011$.

212 The Guardian, November $10^{\text {th }} 2008$.

213 Neuberger Report, para 1.4, citing Lord Irvine of Lairg LC, House of Lords Hansard, HL Debates, November $24^{\text {th }} 1997$, cols 771, 783 and 785 and the Human Rights Act 1998 s2.

${ }^{214}$ Commons Hansard May 23 2011 col 642.

215 [2011] EWHC 1232 at [20] - [21].
} 
"It is not simply a matter of "unaccountable" judges running amok. Parliament enacted the 1998 statute which requires these values to be acknowledged and enforced by the courts. In any event, the courts had been increasingly taking them into account because of the need to interpret domestic law consistently with the United Kingdom's international obligations. It will be recalled that the United Kingdom government signed up to the Convention more than 50 years ago.” 216

Attempts to cast responsibility entirely on the judges or entirely on Parliament are unfortunate. The reality is that the law has developed as a result of both inputs.

\section{WHERE FROM HERE?}

\subsection{Legislative change}

Legislation could more clearly delimit the limits to privacy and its enforcement. Given the "margin of appreciation" allowed to member States within the ECHR to implement Treaty obligations in their own way and in their own legal contexts, ${ }^{217}$ the balance could be drawn differently from that which currently applies. A more extreme response would be to repeal the HRA, so that judges were no longer required to follow the precepts of the ECHR. However, if Britain remained a signatory to the Convention, it would continue to exert an influence, and more detailed laws (such as a "Bill of Rights") would still be needed to introduce principles which differ from the rules set out in current caselaw.

\subsection{Judicial change}

Eady J said in CTB $v$ News Group Newspapers Ltd:

"Parliament may at some stage wish to change the law... but in the meantime the courts are obliged to apply the law as it currently stands.... It is not easy to see... how any significant changes could be achieved other than by legislation." 218

\footnotetext{
216 [2008] EWHC 1777 at [7].

217 See for instance MGN Ltd v U K [2011] ECHR 66, [2011] ECHR 919. The margin of appreciation applies both to legislative action ([2011] ECHR 919 at [200]) and to decisions of the courts ([2011] ECHR 919 at [150]).

218 [2011] EWHC 1326 at [15] - [17]. See also TSE v News Group Newspapers Ltd [2011] EWHC 1308 at [16].
} 
There is more scope for judicial change than this suggests. First, the boundary of private life could be delimited differently, reversing some of the distance which has been travelled since the Theakston decision, without transgressing ECHR obligations. ${ }^{219}$ Secondly, there could be a greater reluctance to use injunctions, reserving them for instances where it is demonstrated that damages would not be a sufficient remedy. ${ }^{220}$ Thirdly, the current approach appears to assume that once a reasonable expectation of privacy has been established, it is worthy of protection by injunction unless good countervailing reasons are demonstrated. That approach could be reversed, as it is in Ireland. ${ }^{221}$ In the landmark decision in Herrity $v$ Associated Newspapers (Ireland) $\mathrm{Ltd}^{222}$ Dunne J held that damages could be awarded in Irish law for an invasion of privacy. ${ }^{223}$ In considering the balance between the rights in the Irish Constitution guaranteeing freedom of expression and privacy $^{224}$, Dunne J observed that “as a general proposition, I think that cases in which the right to privacy will prevail over the right to freedom of expression may well be far and few between". The actions in that case had taken place before the ECHR became part of Irish domestic law, but this general approach was endorsed by Kearns $\mathrm{P}$ in Hickey $v$ Sunday Newspapers $L t d^{225}$ where the events took place after the Convention was incorporated into law.

The Neuberger Report shows how practice has developed between 2010 and the Report's publication in May 2011 to ensure that superinjunctions are likely to be used only in the most exceptional circumstances, and only for the shortest possible period. Other changes proposed in the Neuberger Report ${ }^{226}$ are likely to have an impact. Increased emphasis on the principle that orders should not be granted without notice to the parties affected, including the media, will help to ensure that the courts take full account of all relevant considerations, provided that the media pursues public interest arguments more vigorously, and where a good case is not accepted at trial, appeals. As a matter of principle, a court accepting that reporting should be anonymous

\footnotetext{
${ }^{219}$ See above $\S 2.2$ and 7.5 .

220 See above $\$ 7.5$ and 7.6.

221 See above $\S 4.4$ and 7.6.

222 [2009] 1 IR 316.

223 In this case the disclosure of an affair by a married woman with her Roman Catholic parish priest discovered through illegal phone tapping
${ }^{224}$ An unenumerated human right established by McGee v AG [1974] IR 284 and subsequent cases.
225 [2010] IEHC 349.
${ }^{226}$ Practice Guidance for Interim Non-Disclosure Orders envisaged in the Neuberger Report was launched on August $1^{\text {st }} 2011$.


should always provide its reasons for reaching this conclusion, ${ }^{227}$ and those reasons should be made publicly available. ${ }^{228}$

\subsection{The Leveson Enquiry and Media Self-regulation}

The ability of the media to regulate itself has been called into question recently by scandals involving the interception of telephone messages by reporters acting for The News of the World (and potentially for other newspapers) which have led to the closure of the newspaper and the establishment of a public enquiry in July 2011 led by Leveson LJ. The enquiry is expected to take at least a year before reporting. The enquiry may well make recommendations for more effective protection of personal privacy, and is likely to review the Press Complaints Commission Code of Conduct. As the European Court recognised in the Mosley $^{229}$ case there is a role for press self-regulation. It is possible that exemplary damages can be awarded to redress serious invasions of privacy ${ }^{230}$ and if the Code of Conduct has been breached, this may be a factor in deciding whether such an award is appropriate.

\subsection{Catch 22}

Ryan Giggs could hardly have obtained greater publicity than he achieved through an anonymised injunction. Seeking an injunction may thus defeat its very purpose. This was recognised by the Irish High Court in Foley $v$ Sunday Newspapers Ltd. A notorious criminal known as "the Viper" objected to references to him made in certain publications about underworld gangsters. Kelly J remarked: "the information in question is in the public domain and the bringing of this action with its attendant publicity has given it a much wider circulation.”231 The experiences of Ryan Giggs and Sir Fred Goodwin in seeing their attempts at anonymity backfire may well be a powerful disincentive for others.

\footnotetext{
227 This proposition is tacitly accepted by the Neuberger Report - see paras 1.28 and 3.53 .

${ }^{228}$ As was recommended in JIH $v$ News Group Newspapers Ltd [2011] EWCA Civ 42 at [21(9)] \& [35]. See Neuberger Report para 4.8.

229 [2011] ECHR 774. See above § 3.3.

230 Mosley v News Group Newspapers Ltd [2008] EWHC 2341.

${ }^{231}$ [2005] 1 IR 88 at [60].
} 


\subsection{Do Nothing?}

Doing nothing is nearly always an option, but it is not necessarily the best choice. However, the storm about superinjunctions has blown over almost as rapidly as it started, being displaced by the News of the World telephone hacking scandal. ${ }^{232}$ Any legislative change will be slow in coming but, although controversial, probably eclipsed by other issues in any Bill of Rights, the most likely vehicle for change. In the meantime, most of the arguments have already been deployed; the judiciary is well aware of the controversy about superinjunctions and is now more circumspect; ${ }^{233}$ the implementation of the Neuberger report will equally have an impact; the "Catch 22" dilemma may reduce the number of anonymity orders being sought; and as media interest subsides, internet gossip is likely to wane.

232 See Greenslade, Guardian online, July 26 2011.

233 See for instance Hutcheson (Formerly Known As "KGM") v News Group Newspapers Ltd [2011] EWCA Civ 808. 